\title{
Receptor Assay-Guided Isolation of Anti-GABAergic Insecticidal Alkaloids from a Fungal Culture
}

\author{
TADAHIKO KURIYAMA, ${ }^{\dagger}$ EIJI KAKEMOTO,${ }^{\dagger}$ NOBUtOSHI TAKAHASHI,${ }^{\S}$ KeI-ICHI \\ IMAMURA,${ }^{\S}$ KAZUHIKO OYAMA,${ }^{\S}$ EMIKO SUZUKI, ${ }^{\S}$ KENZO HARIMAYA, ${ }^{\S}$ TAKASHI \\ YAGUCHI, ${ }^{\S}$ AND YOSHIHISA OZOE ${ }^{\dagger *}$
}

Department of Life Science and Biotechnology, Faculty of Life and Environmental Science, Shimane University, Matsue, Shimane 690-8504, Japan; Pharmaceutical

Research Center, Meiji Seika Kaisha, Ltd., Kohoku-ku, Yokohama 222-8567, Japan

Supporting Information 


\section{SUPPORTING INFORMATION 1}

\section{Methods}

NMR spectra were recorded on a JEOL GSX400 spectrometer. Mass spectra were obtained on a JEOL JMS-700 spectrometer. UV and IR spectra were measured on Shimadzu UV-260 and FTIR-8100 spectrometers, respectively. Optical rotations were obtained on a JASCO DIP-370 polarimeter.

NMR data for PF1198A and B

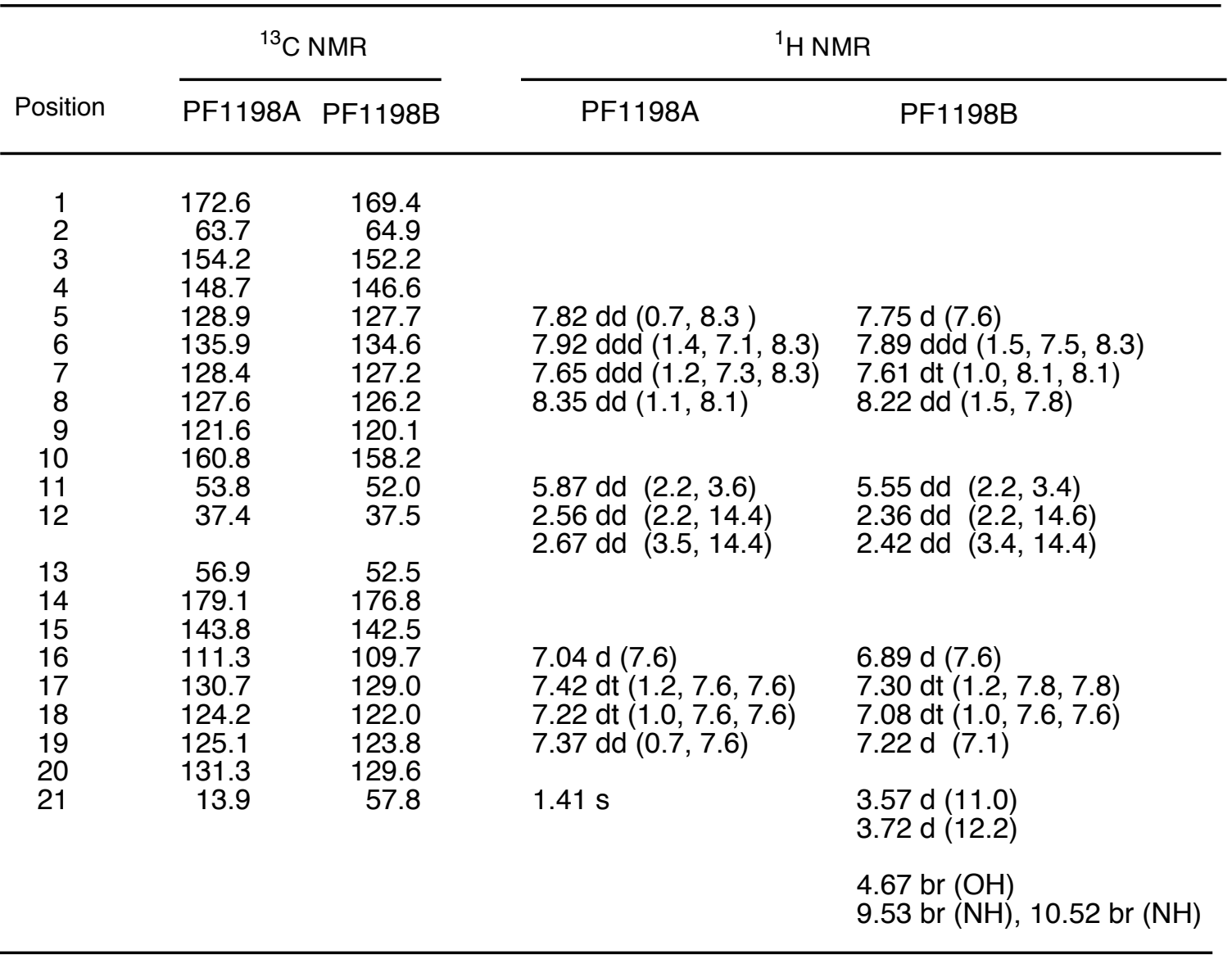

Values in ppm $(J, \mathrm{~Hz})$.

Solvents used: $\mathrm{CD}_{3} \mathrm{OD}$ for PF1198A and DMSO- $d_{6}$ for PF1198B.

PF1198A

$\mathrm{mp}:>250^{\circ} \mathrm{C} ;\left[[]_{\mathrm{D}}=+27.4^{\circ}(\mathrm{c} 0.1, \mathrm{MeOH})\right.$

FAB-MS $m / z: 373\left(\mathrm{MH}^{+}\right)$;

HR-MS $m / z$ : $373.1281 \quad \mathrm{C}_{21} \mathrm{H}_{17} \mathrm{~N}_{4} \mathrm{O}_{3}$;

UV (MeOH) nm: 213, 257, 266, 277, 291, 303, 315;

IR $(\mathrm{KBr}) \mathrm{cm}^{-1}: 1716,1660,1622,1610$.

PF1198B

$\mathrm{mp}:>250^{\circ} \mathrm{C} ;[\square] \mathrm{D}=+21.7^{\circ}(\mathrm{c} 0.1, \mathrm{MeOH})$

FAB-MS $m / z: 389\left(\mathrm{MH}^{+}\right)$;

HR-MS m/z: $389.1254 \quad \mathrm{C}_{21} \mathrm{H}_{17} \mathrm{~N}_{4} \mathrm{O}_{4}$;

UV (MeOH) nm: 208, 258, 266, 278, 303, 315;

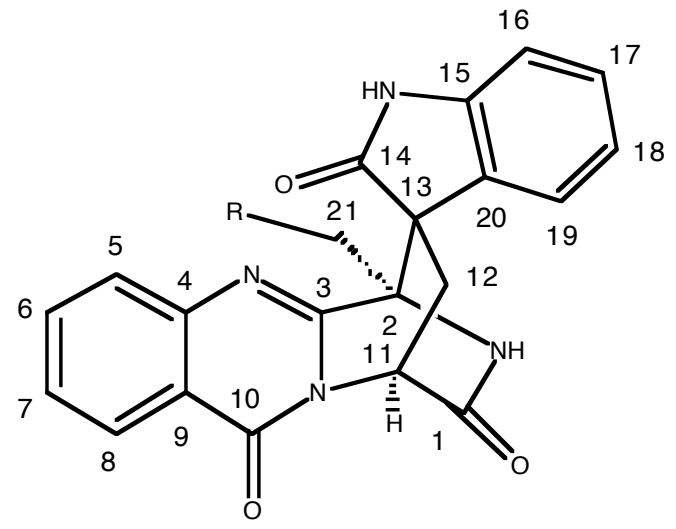

IR $(\mathrm{KBr}) \mathrm{cm}^{-1}:$ 1710, 1622, 1472.

PF1198A (Alantrypinone): $\mathrm{R}=\mathrm{H}$

PF1198B (Serantrypinone): $\mathrm{R}=\mathrm{OH}$ 


\section{SUPPORTING INFORMATION 2}

\section{Aspergillus terreus PF1198}

Taxonomy

Colonies on CYA and MEA: Growing rapidly, yellowish brown.

Aspergilla: Biserate, metulae over the upper half of the vesicle.

Conidia: 2-3 mm in diameter, smooth-walled, globose to subglobose.

\section{Fermentation}

Seed medium: $2.0 \%$ starch, $1.0 \%$ glucose, $0.6 \%$ wheat germ, $0.2 \%$ soybean meal, $0.3 \%$ yeast extract, $0.5 \%$ polypeptone, $0.2 \% \mathrm{CaCO}_{3}$ and tap water ( $\mathrm{pH} 7.0)$.

Production medium: Rice containing water and $2.5 \%$ soybean meal (pH non-adjusted).

Incubation: Stationary phase culture for 14 days at $28^{\circ} \mathrm{C}$.

Electron microscopy

Observations by electron microscopy were performed with a JEOL JSM-6300F electron microscope.

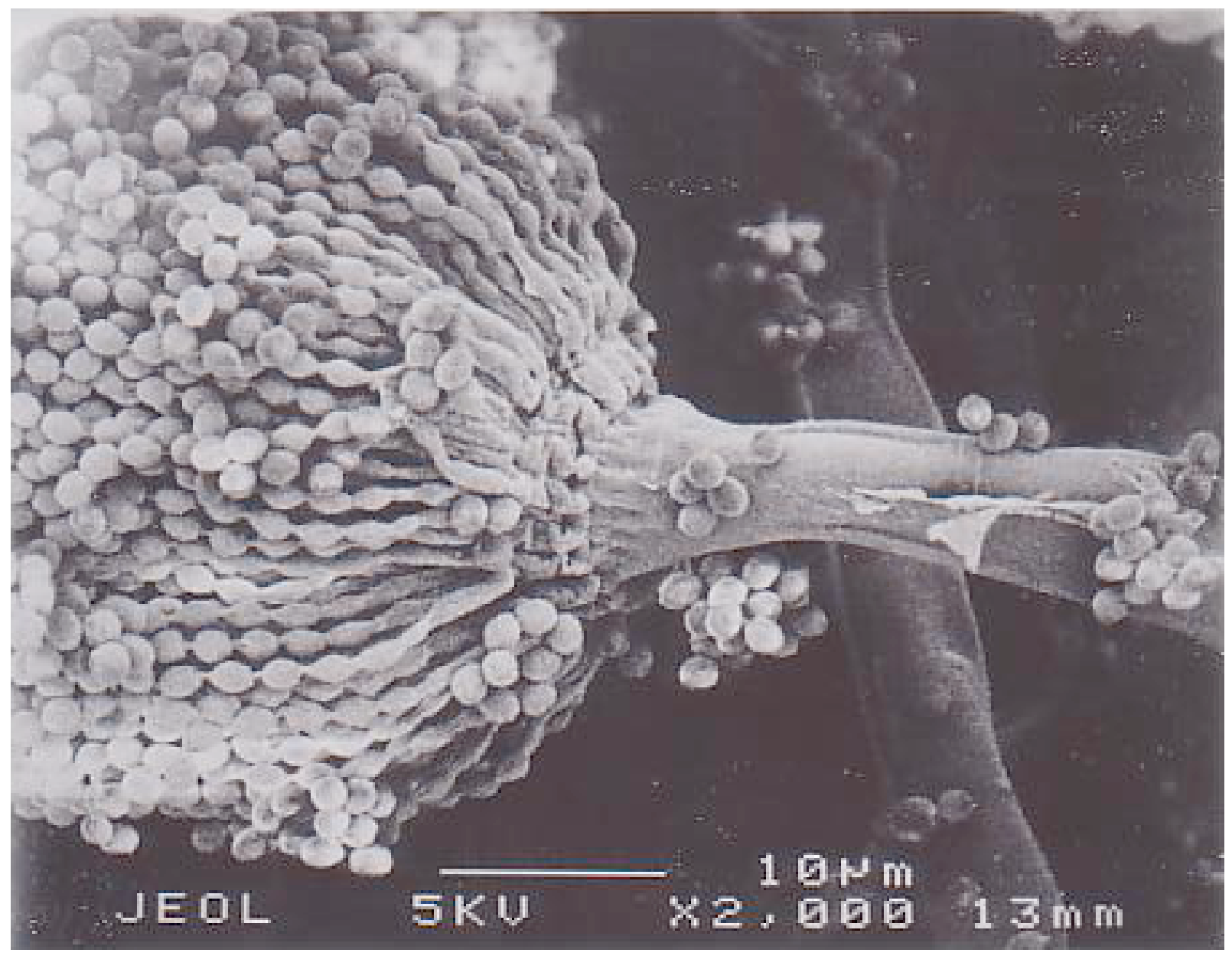

